\title{
Anterior Cruciate Ligament Mechanoreceptors Regeneration Following Reconstruction Using Autografts
}

\author{
Antonios G Angoules* \\ Department of Essential Medical Subjects, Faculty of Health \& Caring Professions, Technological Educational Institute of Athens, Greece
}

Anterior Cruciate Ligament (ACL) reconstruction is a widespread surgical intervention conducting for a common knee injury which results in ligamentous rupture and deficiency [1,2]. With the increased number of people who participate in sports activities these surgical procedures are expected to increase in the upcoming years.

A variety of surgical procedures and also different types of autografts, artificial grafts, and allografts have been used with satisfactory results $[3,4]$.

In recent years two different types of autografts, the Bone Patellar Bone Tendon (BPBT) and the four Strand Hamstrings (4SH) tendons have become the most frequently used graft types for ACL ligament reconstruction [4-8].

Many research papers have demonstrated the regeneration of the tissues, in the area that provides these autografts [9-17].

Magnetic Resonance Imaging (MRI) has documented regeneration of the $1 / 3$ of the patellar tendon which continues to process for 2 years [13-16]. In histological studies, the tendon appears to have a tissue structure that resembles that of a normal tendon [17].

The rebirth of the hamstring grafts consisted of gracilis and semitendinosus tendons is spectacular, since the largest section of the main body of the tendon is surgically detached when degenerated, to be used in ACL restoration procedures as autografts. Regenerated tissue checked by MRI, ultrasound and biopsies although inferior, it has structure and possibly features similar to the original tissue [18-20].

Surgical reconstruction of the ruptured ligament aims to restore not only the static but also the dynamic joint stability, which is considered necessary for the restoration of the knee functionality [21].

ACL plays a critical role to the knee functionality as a static and a dynamic joint stabilizer. This ACL fundamental dynamic role and its crucial contribution to the knee proprioception are guaranteed by the presence of an adequate number of specific ligament mechanoreceptors [21-24].

Proprioceptive deficits following ACL rupture and ligament deficiency are well documented [25-29]. The restoration of the proprioception after ACL reconstruction is also supported in a significant number of research papers [27-30].

Albeit restoration of proprioceptive deficits is possibly supplied by the regeneration of the mechanoreceptors of the autografts, the mechanism which achieves this process is not yet clarified.

Notably interesting appears to be the study of mechanoreceptors regeneration after a surgical reconstruction of the ligament.

Denti et al. [31] reported that in experimental sheep, anterior cruciate ligament reconstruction with autologous patellar tendon resulted in the presence of mechanoreceptors in the reconstructed anterior cruciate ligament. Mechanoreceptors were absent in cases that artificial grafts were used. Additionally in two unsuccessful grafts, there were found histologically normal mechanoreceptors in the $9^{\text {th }}$ and the $10^{\text {th }}$ year postoperatively.

Aune et al. [32] working on laboratory animals and human
ACLs, studied the innervation of the BPBT graft and suggested the reinnervation of the graft. In a rat model, in the $4^{\text {th }}$ postoperative week, immunoreactivity for substance $\mathrm{P}$ was confirmed by histological methods. After the fourth postoperative week the grafts were deemed sustainable, and except for that until the $16^{\text {th }}$ postoperative week sensorineural peptides like calcitonin gene-related peptide and protein gene product 9.5 were detected in these grafts.

Furthermore indication of fully integrated regenerative process was found in all biopsies that examined human specimens isolated from patellar tendon from the $5^{\text {th }}$ to the $37^{\text {th }}$ postoperative month Nonetheless, evidence suggesting immune activity of neural peptides was not detected [32].

In another study Barrack et al. [33] used BPBT grafts in male adult dog models, suggested the regeneration of some nerve elements of the grafts, at least in some cases 6 months postoperatively. Apart from the histological indication of the graft, the researchers managed to confirm the return of the Somatosensory Evoked Potentials (SEP), in 2 of the 6 cases of the laboratory animals.

In rabbits, Simuzu et al. [34] by using BPBT managed to detect an increasing number of mechanoreceptors in the graft at the $4^{\text {th }}$ week after the ligament reconstruction, so that at the $8^{\text {th }}$ week the total amount of mechanoreceptors had reached the normal amount of those in the control group.

In a very interesting study, Ochi et al. [26] recorded somatosensory evoked potentials after electric stimulation in intact and in ruptured ligaments before and after their reconstruction. SEP were detectable in all intact ligaments as well as in those which had undergone a reconstruction with hamstrings graft 18 months after the surgery. On the contrary, in case of a rupture SEP could be detected in half of the cases in the injured group. The authors suggest sensory reinnervation of the reconstructed ACL which is closely related with the knee functionality.

Finally Georgoulis et al. [22] examined neural mechanoreceptors that were present in the remnants of ruptured ACL in a timeframe that included the period from the $3^{\text {rd }}$ week to the $42^{\text {nd }}$ week that followed an injury. They confirmed the existence of viable mechanoreceptors in patients with an ACL vestige grafted onto the Posterior Cruciate Ligament (PCL). They proposed that in case that the reinnervation of the Anterior Cruciate Ligament gives as an end result the restitution of the ligament, a detectable amount of ACL that would act as a source, would be extremely beneficial for the operated.

*Corresponding author: Antonios G Angoules, Department of Essential Medical Subjects, Faculty of Health \& Caring Professions, Technological Educational Institute of Athens, Greece, E-mail: antoniosangoules@yahoo.com

Received September 02, 2013; Accepted September 04, 2013; Published September 07, 2013

Citation: Angoules AG (2013) Anterior Cruciate Ligament Mechanoreceptors Regeneration Following Reconstruction Using Autografts. J Sports Med Doping Stud 3: e136. doi:10.4172/2161-0673.1000e136

Copyright: ( 2013 Angoules AG. This is an open-access article distributed under the terms of the Creative Commons Attribution License, which permits unrestricted use, distribution, and reproduction in any medium, provided the original author and source are credited. 
It is therefore clear from the aforementioned studies that there is evidence of regeneration of the nerve elements of the autografts, which are used for the ligament reconstruction. ACL mechanoreceptors are an integral part of the complex mechanism of the proprioceptive sensitivity of the knee. Their rebirth probably has a positive impact in the proprioceptive improvement, which is recorded after reconstruction of a ruptured ligament with the two most frequently used types of autografts, BPBT and four strand hamstrings.

\section{References}

1. Myasaka K, Daniel D, Stone M, Hirshman $P$ (1991) The incidence of knee ligament injuries in general population. Am J Knee Surg 4: 3-7.

2. Bollen SR, Scott BW (1996) Rupture of the anterior cruciate ligament--a quiet epidemic? Injury 27: 407-409.

3. Fu FH, Bennett CH, Ma CB, Menetrey J, Lattermann C (2000) Current trends in anterior cruciate ligament reconstruction. Part II. Operative procedures and clinical correlations. Am J Sports Med 28: 124-130.

4. Duquin TR, Wind WM, Fineberg MS, Smolinski RJ, Buyea CM (2009) Current trends in anterior cruciate ligament reconstruction. J Knee Surg 22: 7-12.

5. Herrington L, Wrapson C, Matthews M, Matthews H (2005) Anterior cruciate ligament reconstruction, hamstring versus bone-patella tendon-bone grafts: a systematic literature review of outcome from surgery. Knee 12: 41-50.

6. Forster MC, Forster IW (2005) Patellar tendon or four-strand hamstring? A systematic review of autografts for anterior cruciate ligament reconstruction. Knee 12: 225-230.

7. Biau DJ, Tournoux C, Katsahian S, Schranz PJ, Nizard RS (2006) Bonepatellar tendon-bone autografts versus hamstring autografts for reconstruction of anterior cruciate ligament: meta-analysis. BMJ 332: 995-1001.

8. Li S, Su W, Zhao J, Xu Y, Bo Z, et al. (2011) A meta-analysis of hamstring autografts versus bone-patellar tendon-bone autografts for reconstruction of the anterior cruciate ligament. Knee 18: 287-293.

9. Nikolaou VS, Efstathopoulos N, Wredmark T (2007) Hamstring tendons regeneration after $A C L$ reconstruction: an overview. Knee Surg Sports Traumatol Arthrosc 15: 153-160.

10. Choi JY, Ha JK, Kim YW, Shim JC, Yang SJ, et al. (2012) Relationships among tendon regeneration on MRI, flexor strength, and functional performance after anterior cruciate ligament reconstruction with hamstring autograft. Am J Sports Med 40: 152-162.

11. Janssen RP, van der Velden MJ, Pasmans HL, Sala HA (2013) Regeneration of hamstring tendons after anterior cruciate ligament reconstruction. Knee Surg Sports Traumatol Arthrosc 21: 898-905.

12. Macleod TD, Snyder-Mackler L, Axe MJ, Buchanan TS (2013) Early regeneration determines long-term graft site morphology and function after reconstruction of the anterior cruciate ligament with semitendinosus-gracilis autograft: a case series. Int J Sports Phys Ther 8: 256-268.

13. Coupens SD, Yates CK, Sheldon C, Ward C (1992) Magnetic resonance imaging evaluation of the patellar tendon after use of its central one-third for anterior cruciate ligament reconstruction. Am J Sports Med 20: 332-335.

14. Bernicker JP, Haddad JL, Lintner DM, DiLiberti TC, Bocell JR (1998) Patellar tendon defect during the first year after anterior cruciate ligament reconstruction: appearance on serial magnetic resonance imaging. Arthroscopy 14: 804-809.

15. Kartus J, Lindahl S, Stener S, Eriksson BI, Karlsson J (1999) Magnetic resonance imaging of the patellar tendon after harvesting its central third: a comparison between traditional and subcutaneous harvesting techniques. Arthroscopy 15: 587-593.

16. Kartus J, Magnusson L, Stener S, Brandsson S, Eriksson BI, et al. (1999) Complications following arthroscopic anterior cruciate ligament reconstruction A 2-5-year follow-up of 604 patients with special emphasis on anterior knee pain. Knee Surg Sports Traumatol Arthrosc 7: 2-8.

17. Berg EE (1992) Intrinsic healing of a patellar tendon donor site defect after anterior cruciate ligament reconstruction. Clin Orthop Relat Res: 160-163.
18. Cross MJ, Roger G, Kujawa P, Anderson IF (1992) Regeneration of the semitendinosus and gracilis tendons following their transection for repair of the anterior cruciate ligament. Am J Sports Med 20: 221-223.

19. Papandrea P, Vulpiani MC, Ferretti A, Conteduca F (2000) Regeneration of the semitendinosus tendon harvested for anterior cruciate ligament reconstruction. Evaluation using ultrasonography. Am J Sports Med 28: 556-561.

20. Eriksson K, Kindblom LG, Hamberg P, Larsson H, Wredmark T (2001) The semitendinosus tendon regenerates after resection: a morphologic and MRI analysis in 6 patients after resection for anterior cruciate ligament reconstruction. Acta Orthop Scand 72: 379-384.

21. Johansson $H$, Sjölander $P$, Sojka $P$ (1991) A sensory role for the cruciate ligaments. Clin Orthop Relat Res : 161-178.

22. Georgoulis AD, Pappa L, Moebius U, Malamou-Mitsi V, Pappa S, et al. (2001) The presence of proprioceptive mechanoreceptors in the remnants of the ruptured $A C L$ as a possible source of re-innervation of the $A C L$ autograft. Knee Surg Sports Traumatol Arthrosc 9: 364-368.

23. Adachi N, Ochi M, Uchio Y, Iwasa J, Ryoke K, et al. (2002) Mechanoreceptors in the anterior cruciate ligament contribute to the joint position sense. Acta Orthop Scand 73: 330-334

24. Angoules A (2012) The contribution of the Anterior Cruciate Ligament to the Knee Proprioception. J Nov Physiother 2: 3.

25. Barrack RL, Skinner HB, Buckley SL (1989) Proprioception in the anterior cruciate deficient knee. Am J Sports Med 17: 1-6.

26. Ochi M, Iwasa J, Uchio $Y$, Adachi N, Sumen $Y$ (1999) The regeneration of sensory neurones in the reconstruction of the anterior cruciate ligament. J Bone Joint Surg $\mathrm{Br}$ 81: 902-906.

27. Reider B, Arcand MA, Diehl LH, Mroczek K, Abulencia A, et al. (2003) Proprioception of the knee before and after anterior cruciate ligament reconstruction. Arthroscopy 19: 2-12.

28. Angoules AG, Mavrogenis AF, Dimitriou R, Karzis K, Drakoulakis E, et al. (2011) Knee proprioception following ACL reconstruction; a prospective trial comparing hamstrings with bone-patellar tendon-bone autograft. Knee 18: 76-82.

29. Dhillon MS, Bali K, Prabhakar S (2011) Proprioception in anterior cruciate ligament deficient knees and its relevance in anterior cruciate ligament reconstruction. Indian J Orthop 45: 294-300.

30. Risberg MA, Beynnon BD, Peura GD, Uh BS (1999) Proprioception after anterior cruciate ligament reconstruction with and without bracing. Knee Surg Sports Traumatol Arthrosc 7: 303-309.

31. Denti M, Monteleone M, Berardi A, Panni AS (1994) Anterior cruciate ligament mechanoreceptors. Histologic studies on lesions and reconstruction. Clin Orthop Relat Res: 29-32.

32. Aune AK, Hukkanen M, Madsen JE, Polak JM, Nordsletten L (1996) Nerve regeneration during patellar tendon autograft remodelling after anterior cruciate ligament reconstruction: an experimental and clinical study. J Orthop Res 14: 193-199.

33. Barrack RL, Lund PJ, Munn BG, Wink C, Happel L (1997) Evidence of reinnervation of free patellar tendon autograft used for anterior cruciate ligament reconstruction. Am J Sports Med 25: 196-202.

34. Shimizu T, Takahashi T, Wada Y, Tanaka M, Morisawa Y, et al. (1999) Regeneration process of mechanoreceptors in the reconstructed anterior cruciate ligament. Arch Orthop Trauma Surg 119: 405-409. 